\title{
Metropolitan and rural areas fighting for the control of electricity networks in France. A local geopolitics approach to energy transition
}

François-Mathieu Poupeau, Research in the CNRS

(LATTS, University of Paris-Est, France)

\section{Introduction}

The transformation of electricity systems is raising important issues today in Europe regarding territorial inequalities. With different institutional designs between countries (Glachant, Finon, 2003; Wollmann, Marcou, 2010; Birchfield, Duffield, 2011), the opening up of markets to competition is challenging previous models of utilities regulation, which were characterized by an over-riding concern for territorial and social cohesion. All of these models were based on the modern infrastructural ideal, which claimed to ensure a certain degree of homogeneity in treatment among users, against the backdrop of the growth of the welfare state (Graham, Marvin, 2001). They were supported by many mechanisms of solidarity, in production, transportation and provision, organized on national or regional levels. Some of them were very strong, like in France, as they were intended to impose national unified tariffs for certain categories of customers (Poupeau, 2007). Others were weaker, because based on a different conception of social and political integration. With liberalization, this ideal has however been called into question, to the benefit of logics more attuned to differentiation between users and territories. Monopolies are tending to disappear or to be replaced by more numerous public or private operators, which are increasingly segmenting their offers, discriminating between their customers, or making investments targeted at certain appealing areas (Graham, Marvin, 2001). This trend towards territorial differentiation is indirectly supported by the dynamics of decentralization in many European countries. Cities today are the main beneficiaries of governments' locational policies implemented since the 1990s, based on the idea of "necessary" competition between regions as a factor in economic competitiveness (Scott, 2001; Brenner, 2004). As a successor to spatial Keynesianism (1960s-1970s) and endogenous development (1980s) policies, these strategies focus above all on metropolises, which raises the question of the place that is subsequently granted to other regions located on their periphery, which are often rural. This question is raised 
with particular acuteness in the case of energy, where cities are implementing increasingly ambitious and autonomous policies in terms of the development of sustainable energy sources, the fight against climate change, or the deployment of smart networks (Bulkeley, 2013; Urban Studies, 2014; Energy Policy, 2015).

In this article, we argue that these two processes (liberalization, decentralization) result in new kinds of conflict within infra-national territories, and namely between rural and urban areas, concerning the (un)equal access to a "clean", affordable and quality energy. We propose to study them through the concept of "local geopolitics". Borrowed from the study of international relations, geopolitics can be defined as the "analysis of the interaction between, on the one hand, geographical settings and perspectives and, on the other, political processes. [...] Both geographical settings and political processes are dynamic, and each influences and is influenced by the other. Geopolitics addresses the consequences of this interaction" (Cohen, 2015: 16). This concept puts at the heart of the analysis the study of rivalries between actors, whether public or private, local or national, with regard to the control of territory's resources. These resources are multiple: natural (raw materials, water, etc.), economic (access to a market, supply chain or sector of activity), political (holding positions of power) or symbolic (identity, culture). Their appropriation allows actors or groups of actors to be able to develop territorialization strategies, which Robert Sack defines as "the attempt by an individual or a group to affect, influence, or control people, phenomena, and relationships, by delimiting and asserting control over a geographic area. This area will be called the territory" (Sack, 1986: 19).

Due to their importance in daily life, energy issues are at the heart of new geopolitical issues. They have been the subject of many studies in international relations analysis (Goldthau, 2013; Considine, Paik, 2018; Davidson et al., 2018; Goldthau et al., 2018), focused on regions (Middle East, Europe, America, Asia, etc.), social or environmental issues (climate change, poverty and development, etc.), resources (oil, gas, renewable energy, etc.), sub-sectors (production, infrastructures, provision, housing, etc.), or types of actors (state, international organizations, private companies, NGOs, etc.). But very few researches have applied this concept to analyse ongoing processes of energy transition on a national and infra-national scale. Instead, they have preferred to use the notion of governance. In our opinion, 
however, the concept of geopolitics is particularly useful for analysing the emerging conflicts attending these processes. Whereas governance is more appropriate for describing coordination processes and the state of relationships and power struggles, geopolitics aims to link them to an in-depth analysis of the resources targeted by appropriation strategies. This approach requires us to adopt a dual perspective. The first step consists in mapping a "territorial political economy" of the sector under scrutiny, in order to identify what kind of resources are at stake for local actors, in terms of geographical settings. The second step implies focussing on the political strategies that these actors try to develop to control these resources, and the different means and networks they mobilize.

To illustrate this, we will consider the example of the institutional power struggles in which metropolitan and rural elected officials have taken part for the control of public electricity distribution networks in France. This country is strongly affected by the problem of territorial differentiation, given its geographic and political features: $23 \%$ of its population still lives in rural areas, without counting the outskirts of cities, which are often urban-rural hybrids. Its population density is 112 inhabitants $/ \mathrm{km}^{2}$ (compared to 231 for Germany, 251 for the United Kingdom, 198 for Italy and 77 for Spain ${ }^{1}$ ), which results in comparatively high network investment and operation costs, for energy as well as other public services (digital networks, postal services, railway transportation, etc.). Moreover, France is characterized by a conception of the public service as being highly unified and centralized, concerned about equality among consumers (Jacobin tradition). Territorial solidarity expectations are therefore elevated and are likely to rally numerous actors. These two characteristics (geographic and political) make this country an interesting case for studying the processes of territorial recomposition between metropolitan and rural areas.

Based on a corpus of several field studies ${ }^{2}$, we show that French local institutional disputes around the control of electricity networks reflect a real ability of rural actors, located on the periphery of metropolitan areas, to resist the territorial recomposition processes threatening them. To prevent their regions from being relegated to the simple status of a passive hinterland of large metropolitan centres, many local elected officials have been mobilizing against these trends, and seeking to participate in territorial recomposition. Grouped together around long-standing institutions that 
are very powerful both locally and nationally, they have successfully built a political counter-power that is impeding metropolises' quest for emancipation. By examining these types of actor, which are rarely taken into account in territorial governance research, we show that metropolises' capacity for action must be studied along with the local geopolitical field to which they pertain.

To this end, we have divided our article into three sections. First, we present a "territorial political economy" in the French electricity sector by showing the place that local authorities occupy within it. In particular, we show that their room to manoeuvre is concentrated primarily around public electricity distribution networks, for which they have strong albeit emerging competence. We then analyse the strategies used by local actors, both rural and metropolitan, to control these infrastructures. Seriously taking into account the question of time is crucial, since the processes of change we describe cannot be understood without been placed in a long-term perspective, as proposed by James Mahoney and Kathleen Thelen (2010) in their theory of gradual institutional change. In the second section, we show how the rural world has been able to anticipate the neoliberal reforms of the 1990s-2000s in order to position itself as a key player in the territorial regulation of these networks, through a strong alliance with the state and EDF (Électricité de France), the public utility which at the time had the monopoly. The third section is devoted to the reaction of metropolises, which more recently have been trying to free themselves of this regulatory framework by seeking increased autonomy and differentiation. It shows that this strategy runs into numerous difficulties, due to the previous compromises negotiated with EDF and the state, which still significantly limit the leeway of large cities in terms of public energy distribution.

\section{The territorial political economy of the electricity sector in France}

Before moving on to the study of rivalries between metropolises and the rural world, it appears necessary to place them in a more general context: that of the electricity sector in France and the role played by territorial authorities in its regulation. This first stage is essential for understanding the nature of the stakes in the tug-of-war between rural and metropolitan elected officials. Contrary to popular belief, the role of 
local authorities is not negligible in France. We will see this with regard to a highlydelimited yet major sector: public energy distribution networks. Today, the control of this infrastructure constitutes the very core of local conflicts around stakes that are both financial (benefiting from a share of the profits generated by the operation of networks) and political (defending certain types of users, being able to implement public energy transition policies).

\section{A fundamental jurisdiction of communes: AODE status}

To fully understand current conflicts in France, we have to remember that the management of energy networks (electricity, gas, heating networks) has always been shared between the state and local authorities (research study 1 , see methodological annex). This particularity distinguishes this country from other unitary states, such as Great Britain, in which local authorities' powers were limited and then removed, starting in the 1930s (Hannah, 1979), even though recent dynamics seem to be reinitiating new recomposition (Hannon, Bolton, 2015). In France, an entire centralization process of this type never took place, despite the extensive state intervention from the 1930s and the nationalization of the energy sector in 1946 (Frost, 1991; Lévy-Leboyer, Morsel, 1994; Chick, 2007; Poupeau, 2017). The Communes in France $^{3}$ have always conserved the status of "energy distribution organizing authorities" (AODE, autorités organisatrices de la distribution d'énergie), which was granted to them by the Law of 15 June 1906. The model is based on concessions, as in Germany. The commune signs a concession contract with an operator (usually from the private sector and, after nationalization, with EDF) that grants it a service monopoly within its territory for 20 to 30 years. In exchange, the commune has the right to monitor rates and the investment policy, and becomes the owner of the assets at the end of the contract. This urban service model, which is widely used in other utilities in France, such as water (Lorrain, 1992), gives elected officials an important role in supplying electricity and gas. 
In France, regulation of the electricity sector was based on the framework Law of 15 June 1906, which has never been repealed. This initial framework has however changed substantially since the early $20^{\text {th }}$ century in favour of the state. Without being eliminated, the communes' jurisdictions have been progressively reduced. Today, they hold power essentially over infrastructure management, whereas rate issues, initially included within concession contracts, largely escape from the control of AODEs. In the long-term, two main changes have taken place, which have led to this new equilibrium between the state and the communes.

The first change was related to the creation of EDF in 1946, following the nationalization of former private companies. The state, which controlled this public monopoly, encroached upon the communes' jurisdictions regarding electricity distribution. Rates subsequently became a domain shared with the Ministry of Finance, which wanted to make them a tool of its macro-economic policy to fight inflation. Investments were likewise more strictly controlled by the state, which held the reins of the post-war economy (Kuisel, 1984; Frost, 1991). In this new context, local authorities lost ground but continued to wield real influence. For political reasons, they conserved their AODE status, as supporters of nationalization believed that this was the price to pay to rally local elected officials. The maintenance of this jurisdiction had significant effects, as it required the state and EDF to include communes and their representatives in important strategic decisions made by the government (Poupeau, 2017). This local influence was above all exercised to the benefit of rural areas through the action of an intergovernmental network (Rhodes, Marsh, 1992): the Fédération nationale des collectivités concédantes et régies (FNCCR, National federation of licensing authorities and government corporations). The FNCCR, created in 1933, grouped together several thousand French communes that believed it was necessary to join forces to push the state to intervene and to implement more ambitious public policies (e.g. lower rates, electrification of the territory). The FNCCR was at the time essentially composed of rural elected officials, which held the majority in its governance bodies (board of directors, work groups). On the other hand, city elected officials had far weaker representation within it, which limited their ability to be heard. They nevertheless preferred to allow the FNCCR to 
act instead of creating a competing structure likely to weaken communes as a whole with respect to the state and EDF. This over-representation of the rural world was found in the struggles of the FNCCR during the period of the public-sector monopoly, and weighed in favour of a very high degree of territorial integration between cities and the countryside. The association was successful in securing total unification of electricity prices, in spite of opposition from EDF, which preferred to maintain different rates for rural and urban users (Poupeau, 2007). It was also successful in obtaining massive investments in rural areas thanks to a fund, the FACÉ (Fonds d'amortissement des charges d'électrification), the annual budget of which amounted to 500 million euros in the $1950 \mathrm{~s}-1960 \mathrm{~s}^{4}$. In exchange for these measures aiming to unify the national territory, the FNCCR supported EDF and the state in their centralization policy.

The second change arrived with the liberalization process, which was launched in Europe at the end of the 1980s (Mc Gowan, 1996; Matlary, 1997). It resulted in a second reduction in the local authorities' field of action. From that point on, reforms separated energy supply from network management (the unbundling principle) - two activities that had previously fallen within the scope of concession contracts. The former was entirely opened up to competition, with only a limited intervention by communes (in the name of the free choice of consumers). Only the latter remained within their jurisdiction, as it constituted a natural monopoly that had to be regulated by the public authorities. The communes remained the owners of distribution networks and ensured regulation, alongside the state and through the contracts that they signed with EDF-ENEDIS, which operated distribution networks. Figure 1 represents the new institutional landscape in France that resulted from these reforms, from the point of view of local authorities' action.

Public electricity distribution is now regulated by two main players: the Commission de régulation de l'énergie ( $\mathrm{CRE}$, the energy regulation commission) on the one hand, and the communes on the other. The CRE, a state agency, plays the role of a "competition police". It fixes the transportation rate, the TURPE (Tarif d'utilisation des réseaux publics d'électricité), which is a sort of toll compensating EDF-ENEDIS, the national firm responsible for operating and developing distribution networks ${ }^{5}$. It also ensures that this company does not develop anti-competition practices with respect 
to electricity suppliers (EDF-ENEDIS is an EDF subsidiary). The communes are the AODEs (and the owners) of public electricity distribution networks (Law of 15 June 1906). In this capacity, they grant a monopoly over network operation to EDFENEDIS, in exchange for royalties. Currently, this jurisdiction is highly restrictive, as communes cannot put EDF-ENEDIS under competition (unlike other countries, where this market is open to competition). They moreover all play the role of controlling the level of investments and the quality of the electricity supply (number and time of outages, efficiency in breakdowns, etc.). They are also involved with the CRE in setting the TURPE amount, about which they are consulted. However, their responsibilities may increase in the near future, with the potential opening to competition of concessions held by EDF-ENEDIS. Such a prospect, which regularly comes into play in debates, would constitute a true upheaval within the sector, likely to offer the communes more room to manoeuvre.

Figure $\mathbf{n}^{\circ} \mathbf{1}$. Local authorities in the electricity sector in France in 2019

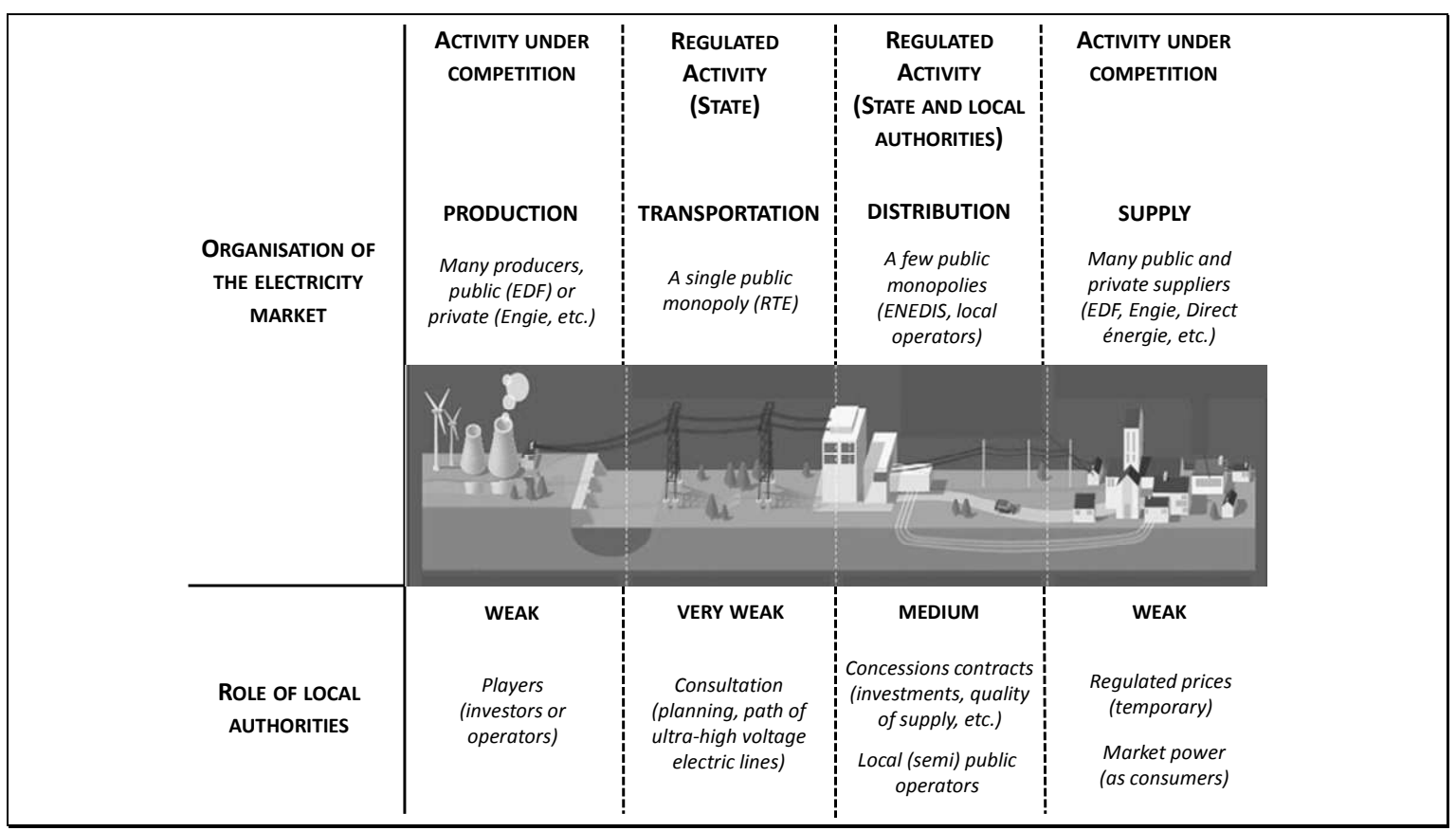

EDF: Électricité de France; ENEL: Ente Nazionale per l'Energia Elettrica ; RTE : Réseau de transport d'électricité. 
This brief presentation shows that one of the main issues for local public authorities today is to control the jurisdiction of public electricity distribution. It constitutes the heart of their current power (and above all that to come) with respect to other fields such as production, transportation and supply, for which they possess far less significant levers for action. In the current context of energy transition, this issue is manifest in three ways.

The first concern is financial. Given that French communes are the owners of public electricity distribution networks, they have exceptional wealth (37 billion euros in $2013^{6}$ ), which they could capitalize on in the event of EDF-ENEDIS coming under competition. It is therefore important for them to ensure that the public operator does not depreciate this wealth, whether through inadequate investments or through accounting operations to their detriment (removing assets from the concession to appropriate them for itself). Moreover, AODEs have access to concession royalties (316 million euros in $2014^{7}$ ) and a portion of local electricity taxes (400 million euros in $2011^{8}$ ). These very large sums constitute substantial budgetary resources in the context of reduced public expenditures that France has experienced since the beginning of the 2000s (and some of which can be put to uses other than electricity). In the event of opening up to competition or even privatization, these financial flows may increase, especially in urban areas, in which the concessions generate the most income.

The second concern for local authorities is to ensure that consumers (individuals, companies, etc.) located on the outskirts of their concession pay the lowest possible distribution costs in order to defend their territory's appeal (population maintenance, economic competitiveness). This takes place through action on the TURPE, which accounts for, respectively, around $30 \%$ and $50 \%$ of low- and high-voltage prices ${ }^{9}$. While communes as a whole are presenting a united front to lower the delivery rate paid to EDF-ENEDIS, their interests diverge regarding the territorial differentiation of the TURPE. Rural communes wish at all costs to maintain the single rate secured after 1946 via the FNCCR, although at the risk of passing excessive increases on to 
their users. Urban areas, on the other hand, and especially metropolises, know that their inhabitants would be the first to benefit from the end of equalization.

The third concern is to compel EDF-ENEDIS to invest in concessions in order to have leeway in implementing public energy transition policies. In this respect, we have to be careful by using the notion of post-networked society, even in the case of cities (Coutard and Rutherford, 2011). We have found that in many territories, the energy transition process is always accompanied by a demand for reliable distribution networks, especially for electricity. These infrastructure elements constitute essential levers in developing renewable energy sources (which are intermittent), electromobility (which requires numerous charging stations for electric vehicles), and smart networks (smart cities or smart territories projects). In a context in which EDFENEDIS has limited financial room to manoeuvre ${ }^{10}$, it is important for local elected officials to attempt to best seize their resources to draw them toward their territory. In this context once again, rivalries come between local authorities.

\section{AODE status: A subject of disputes between metropolitan and rural elected officials}

These three main concerns feed a large number of rivalries between local elected officials around the control of AODE jurisdiction. Possessing it allows them to engage in more favourable power relations with EDF-ENEDIS and the state on these three fronts, in a context characterized by the eventuality of the complete opening of the market to competition. It also allows them to be able to better shape the future of the energy landscape in favour of increased territorial differentiation or, on the contrary, the maintenance of a degree of integration inherited from nationalization. As a result, in the 1990s an initially latent and then open conflict materialized, primarily between two types of local institutions: energy syndicates and metropolises. The former originated in the rural electrification syndicates that up until then had managed work and public subsidies on behalf of the communes (the Facé funds, mentioned above). Initially composed of rural communes, they sought to expand their perimeter to a larger scale, that of the département ${ }^{11}$, by encouraging membership of new municipalities, many of which were located on the outskirts of large cities. They also sought to acquire AODE status, which they did not yet all have. As for metropolises, 
they appeared as institutions in the 1990s based on large cities (Paris, Lyon, Marseille, Lille, etc.) present within the French territory. Their goal was also to get back the AODE jurisdiction from the communes located in their close suburbs, contrary to the strategy of energy syndicates. In addition to the issue of boundaries, these two actors also opposed one another regarding the content to include in future concession contracts: Is it necessary to propose a single model regardless of the territory? On the contrary, is it necessary to differentiate clauses as a function of the type of AODE (rural or metropolitan) in terms of rates or investments? It is around these two main issues (the scope and content of the contract) that a new "local energy geopolitics" has come to be structured in France.

\section{Attack: The rural world}

After having identified the stakes for local authorities in the electricity sector (around the regulation of distribution networks), it is necessary to analyse the processes through which metropolitan and rural actors try to control this resource in order to influence the energy transition trajectory. While some may have thought that reforms in the electrical sector would mainly have benefited metropolises in their quest for autonomy from the central state (Le Galès, 2002), this was not the case. No such process was underway in France when liberalization put an end to energy management by large public monopolies. On the contrary, in the local institutional landscape that emerged from the 1990s, rural elected officials immediately played a major part, which somewhat stifled large cities. To understand this, it is necessary to include the institutional variable, in a medium-term perspective (Mahoney, Thelen, 2010), and take into account the context in which the first reforms were deployed. This demonstrates the significant weight of the rural world in France via a network of local institutions (energy syndicates) relayed by a powerful national association (the FNCCR). Rather than being marginalized, this network was successful in using reforms to strengthen its position. It did so by securing the uniformity of concession contracts across the entirety of the French territory, from the state and EDF-ENEDIS, and by monopolizing the AODE jurisdiction of the majority of communes. 
We have seen that the period preceding the liberalization process did not eliminate all forms of influence of local authorities. They remained active in the regulation of the energy sector through the actions of the FNCCR at local and national levels. At the end of the 1980s, this organization still federated a large majority of communes, many of which were grouped within electrification syndicates. It maintained its political and administrative power thanks to its relays in the senate and the state. This network of actors reacted very quickly when the European Union created its first projects to liberalize the energy sector (Mc Gowan, 1996; Matlary, 1997). It feared that the reforms would lead to total dismantling of the electricity sector, including distribution, causing EDF-ENEDIS to be placed under competition and concession contracts to be renegotiated. This process could benefit large and medium-sized cities, which were densely-populated territories and were therefore profitable and very appealing to new operators. Placed in a position of power, cities could challenge the territorial homogenization strategy advocated by the FNCCR and its network of syndicates since the time of nationalization. Rates might once again become differentiated by commune, along with the investments and financial resources (royalties, taxes) tied to contracts.

This scenario did not however come to pass (research study 2). On the contrary and paradoxically, the first reforms benefited the rural world. To understand this, we have to bear in mind that EDF had no interest in having its distribution branch (ENEDIS) crushed, to the benefit of private companies. Distribution generated substantial revenue that was useful to EDF for developing its production facilities and its transportation networks, and for supporting its international development strategy. The public corporation therefore sought to secure it in order to better control the opening of the market to competition. To do so, it could count on the support of the French state, which followed a strategy very different to that of Great Britain: not dismantling EDF but rather turning it into a "national champion" in the conquest of new global markets. It could also count on the support of rural elected officials, whose interest was to preserve a form of centralization from which they benefited. 
In this context, EDF-ENEDIS made the choice to strengthen its alliance with the FNCCR and its network of electrification syndicates (research studies 2, 3 and 4). It decided to choose them as privileged partners to negotiate new concession contracts well before reforms were implemented (Poupeau, 2004, 2015). These contracts, signed for a period of 20 to 30 years, allowed it to anticipate changes and to prevent sudden dismantling. The new treaties provided for a single electricity rate, which addressed the demands of rural elected officials. They also provided for identical clauses for urban and rural communes in terms of investment policy and partnerships. Lastly, they planned to reassess the amount of royalties paid to communes (about 100 million euros), giving preference to electrification syndicates that covered an entire département, so the more communes that joined, the more money they would receive. The mechanism incentivizing association was simple. It was based on two newly-created royalties. The first one, called "R1" (or "operation royalty", redevance de fonctionnement), was intended to allow the AODE to exert control over the concessionary EDF-ENEDIS (hiring of one or more qualified technicians, potential outfitting, etc.). The second, called R2 (or "investment royalty", redevance d'investissement), compensated for a portion of the expenses that AODEs could incur on electricity networks. These two royalties were established in order to drive communes to group together. The calculation formula contained a multiplier factor which was a function of the population covered by the concession: $1+\mathrm{P}_{C} / \mathrm{P}_{D}$ (where $\mathrm{P}_{\mathrm{C}}$ : concession population; $\mathrm{P}_{\mathrm{D}}$ : population of the département where the concession was located). Therefore, a syndicate totalling $100 \%$ of the inhabitants of its département would benefit from double the royalties, whereas a factor of only 1.2 would be applied to one that covered only $20 \%$ of the département. This difference could represent several million euros in certain territories. Through this highly incentive system, EDF-ENEDIS was clearly playing into the hands of the FNCCR and its network of departmental syndicates in their battle against cities.

Forcing the rural-urban union: The renewal of old local institutions

This strategy significantly modified the local institutional energy landscape, driving many communes to either establish ad hoc departmental energy syndicates where one did not yet exist, or to join those that existed by transferring their AODE 
jurisdiction to them. In all départements, the directors of the FNCCR and EDFENEDIS organized meetings to present the financial advantages of the operation. They also visited reluctant elected officials in order to negotiate certain benefits with them (transferring a portion of the royalties and taxes from the syndicate to the commune). At the end of 1992 there were already around 10 contracts signed with syndicates grouping together on average $97 \%$ of the communes in their département. In 1994, 56\% of French communes had signed the new terms. This number had increased to $84 \%$ by the end of 1997 , which represented $82 \%$ of the French population (Poupeau, 2004).

This departmental grouping dynamic was facilitated by multiple subsequent laws (2006, 2010) (research studies 3, 4 and 11). They were the result of pressure from the FNCCR on the Ministry of the Interior, which was seeking to rationalize the French administrative map by eliminating certain levels or by mutualizing certain technical jurisdictions. Large technical networks (energy, water, transportation, etc.) in particular were targeted at the time. Due to this support from both EDF-ENEDIS and the Ministry of the Interior, by the end of 2010 there were 85 departmental energy syndicates in metropolitan France (out of 90 départements), which reflects the success of the strategy implemented by the FNCCR.

Within two decades, the process of the "departmentalization" of public electricity distribution has therefore progressed considerably. Energy syndicates are becoming increasingly unavoidable institutions not only in the domain of electricity but also beyond it, in the management of large technical systems (research study 11). Whereas they previously took care only of rural electrification credits, they have become AODEs for public electricity distribution networks. The majority of syndicates have also diversified their activity, spreading into public lighting, management of the energy demand, cartography, grouped energy purchasing, or the production of renewable energy (wind, biomass, etc.). Some of them focus on other types of utilities, such as gas, waste, or digital networks, which have also led to the appearance of high stakes in terms of city-countryside inequalities. This transformation demonstrates the power of the rural political lobby, which is capable of mobilizing to avoid being subject to neoliberal reforms. 
The network of departmental syndicates remains heterogeneous across territories ${ }^{12}$ (cf. figure $n^{\circ} 2$ ). Not all rural elected officials are capable of seizing the opportunities offered to them by the new contractual framework. Some of them are unable to overcome the reluctance of small cities or communes located on the outskirts of metropolises, which are tempted to conserve their autonomy (AODE status) while awaiting the opening to competition that they believe to be in their favour. Others have run into political conflicts, which are at times based on disputes between people (retaining control of the AODE to not play into the hands of an adversary). Three syndicates (Vendée, Sipperec, in the suburbs of Paris, and Calvados) with a budget of over 120 million euros and a staff of more than 40 people have broken away very clearly through the breadth of their means and fields of action (top right in figure $\mathrm{n}^{\circ} 2$ ). They have a wide range of activities and are very important public investors within their territory (for the Sipperec, see Bellanger and Poupeau, 2013). However, many other syndicates are less organized and still aim to strengthen their position within the local politico-administrative landscape (bottom left in figure $n^{\circ} 2$ ). Their rise to power has been slower. For all of these syndicates, the concern has since been to maintain their leadership at a time when metropolitan authorities are attempting to carve out a place for themselves in the regulation of energy issues.

Figure $\mathbf{n}^{\circ}$ 2. Distribution of energy syndicates in relation to their budgets and staff $^{13}$ (2010)

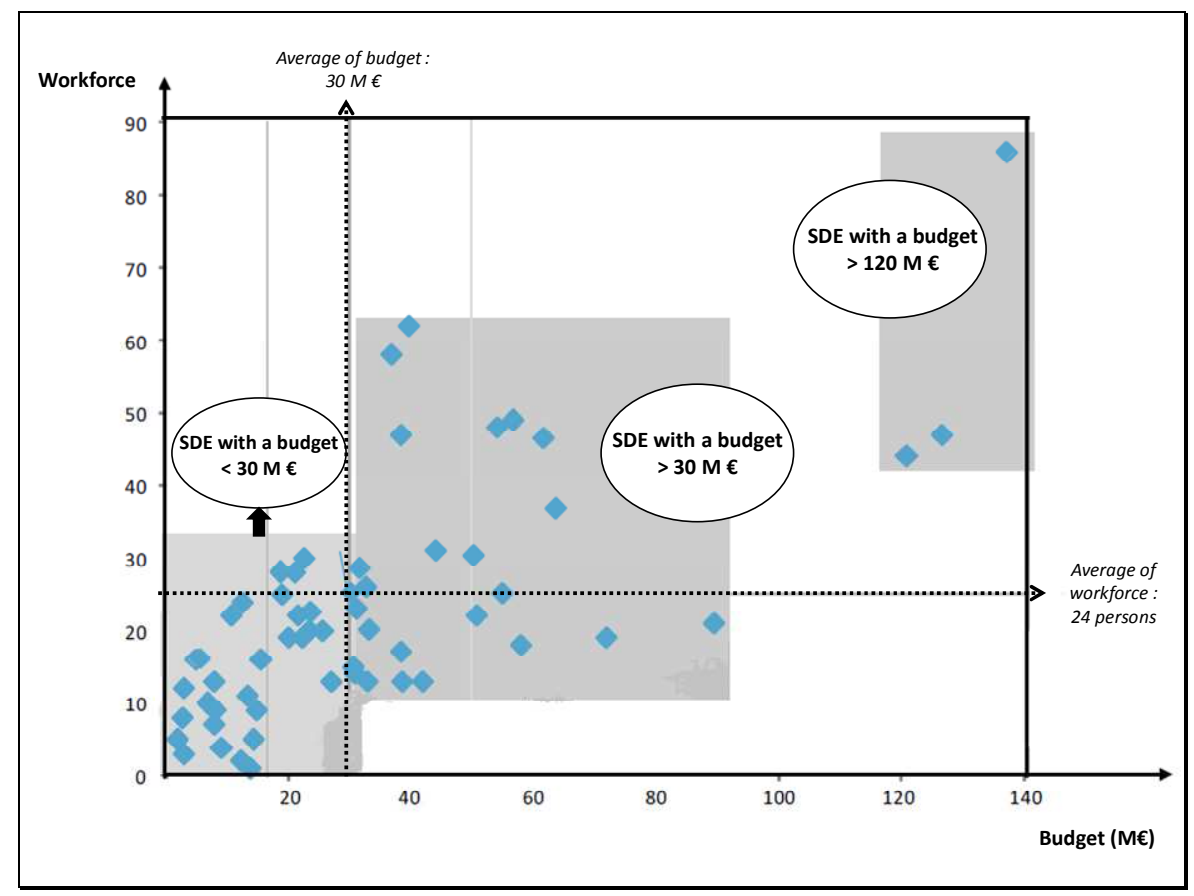

SDE: Syndicat départemental d'énergie. 


\section{The counter-attack: The late reaction of metropolises}

Faced with this rural dynamic, metropolitan elected officials were outpaced for a long time. They attempted to react but met with little success, as they were confronted with a coalition of very powerful actors composed of EDF-ENEDIS (hardly inclined to lose its monopoly), the state (which sought to support its national "champion"), and rural elected officials (dedicated to conserving a high degree of territorial solidarity). Most importantly, up until recently, large cities did not have any lobby comparable to the FNCCR, and existing organizations (such as the AMGVF ${ }^{14}$ ) were not sensitized to public energy distribution issues. It was only very progressively, with important laws on the establishment and strengthening of metropolises $(2014,2015)$, that the hegemony of the rural world was gradually challenged.

From energy-climate plans to networks: The recognition of a metropolitan AODE jurisdiction

Starting in the 2000s, France, along with other countries, came to actively support the creation of metropolitan institutions (Brenner, 2004). This creation was based on existing large cities, to which several communes located on their outskirts were added. At the time, multiple municipal jurisdictions were transferred to metropolises: economic development, urban planning, public roads, culture, etc. The management of large electricity and gas networks was nonetheless an exception, despite it constitutes an essential element in the competitiveness of these territories. In reality, the state did not dare to touch the existing governance system and the role of departmental syndicates out of fear of going against rural elected officials and EDFENEDIS. It preferred to put emphasis on other public policies deemed to be more of a priority. With regard to energy, it was more around climate change and energy efficiency issues that the new metropolises positioned themselves in the beginning, through the POPE ${ }^{15}$ (13 July 2005) and Grenelle II (12 July 2010) laws (research studies 3,5 and 7). The former introduced a new jurisdiction in support of actions to control the energy demand (to help consumers to reduce their expenses). The latter made it mandatory to draw up territorial energy climate change plans (PCET, plans climat énergie territoriaux), in order to implement France's international commitments 
in terms of greenhouse gas reductions. However, these were limited jurisdictions, which did not have an effect on the control of public electricity distribution networks and the structuring of the energy market.

The systematic transfer of AODE status from communes to metropolises did not start until the 2010s. Before that, only a few large cities (Dunkerque, Nantes, Nancy and Brest) had succeeded in becoming AODE through strong political will. Elsewhere, metropolises collided with the reluctance of communes located on their outskirts, either because they already belonged to a departmental syndicate (following the process described before), or because they were reluctant to entrust excessive power to the metropolitan government. To overcome these obstacles, the issue of obligatory transfer was put on the political agenda by France urbaine, an association that has represented the interests of metropolises since 2015 (research study 6). The elected officials of large cities became aware of the importance of AODE status for the implementation of energy policies in terms of planning and financing. The subject was addressed multiple times during the national debate on the energy transition, organized by the state (2012-2013, research study 5), and above all during discussions resulting in new decentralization laws during the $2010 \mathrm{~s}^{16}$. On this occasion, the representatives of metropolises demanded new transfers of responsibility. A harsh debate with the FNCCR ensued. The latter feared a decline in departmental energy syndicates, which could lose their communes located on the outskirts of large cities. This reduction would have significant political and financial consequences. Politically, it would weaken the rural world on the institutional level (as syndicates would federate a smaller population), and financially, it would result in significant revenue losses, amounting to millions of euros in certain cases. The FNCCR, whose future was at stake, mobilized its full political weight (parliament, the Ministry of the Interior) to limit this risk (research study 5).

A compromise was finally found between the FNCCR and representatives of metropolises during the vote on the MAPTAM law in 2014. Since then, the metropolises have had AODE status for public distribution networks for electricity, gas, and heating/cooling ${ }^{17}$. However, the communes that belong to the metropolitan areas are not obliged to leave energy syndicates if they have already joined one. If they wish to remain within the syndicates (and to retain the advantages derived from 
them), they are represented by metropolises within government bodies ("representation-substitution" principle). The law therefore enacted the obligation of cooperation, which was subsequently strengthened by a law on energy transition (7 August 2015). While it required syndicates to implement joint consultation commissions to better include the requests of metropolises, it also and above all allowed them to conserve numerous communes, at times playing on their fear of being absorbed by their powerful metropolitan neighbour.

\section{Between cohabitation and conflict: A brief summary of new local geopolitics}

These changes have resulted in multiple local geopolitical configurations (research studies 7 and 8 ). It is possible to distinguish two main cases. In certain situations (Nantes, Lille), the boundaries of metropolises and syndicates do not overlap, which has not resulted in direct conflict. Since then, the two actors have cohabited more than they have cooperated. In Dijon, for example, the metropolis manages its own public policies (smart networks, the fight against greenhouse gas emissions, the development of renewable energy, etc.), without strong ties with the syndicate that surrounds it. In other cases, such as Lyon, the boundaries of the metropolis and the syndicate overlap and have required the implementation of forms of coordination in order to avoid a crisis in the governance of electricity networks (inability to agree on the investments to be made, absence of a unifying project, etc.).

In the latter case, tensions appeared primarily around the issue of the representation of the metropolis within energy syndicate governance bodies. This has been an important issue for metropolitan elected officials: it consists in ensuring that the problems of metropolis are not ignored by the syndicates, which are often insensitive to urban issues, to the links between energy and transportation, and to climate change issues (unlike cities, they are not responsible for energy-climate plans). Therefore, it is not surprising that conflicts have emerged around representation rules. While the MAPTAM Law has imposed a ceiling on the representation of metropolises at $49 \%$ of voting rights, it has not given any precise indication of the method for calculating the seats. Metropolises have emphasized the population criterion because it favours them (around $49 \%$ of the total number of seats would 
belong to them in certain cases). Syndicates, on the other hand, argue for the criterion of investments to implement across the concession territory, as it prioritizes rural areas and their significant needs in this regard. Many conflicts, some of which still endure today, clearly demonstrate that even when required to grant a larger place to metropolises, departmental energy syndicates do not give up their leadership in terms of network regulation.

\section{A new "contractual Yalta" between metropolises and energy syndicates}

Parallel to this process, metropolises attempted to review the concession contracts signed in the 1990s with EDF-ENEDIS (research studies 8 to 10). As we saw in the second section, at the time, these contracts had been highly favourable to rural elected officials. The latter had obtained numerous advantages for their syndicates, while retaining a system with little differentiation between territories (single rate, identical terms). Faced with the centralizing coalition composed of the FNCCR, EDFENEDIS, and the state, the representatives of metropolises had only been successful in obtaining minor adjustments, in the form of a "large cities protocol" (Poupeau, $2004,2015)$. This charter, of a non-contractual nature, was somewhat more attuned to the particularities of metropolitan territories, in the form of partnerships (development of electric vehicles, participation in local projects, etc.). However, the political economy of concession contracts remained fundamentally unchanged, as neither EDF, nor the state, nor the FNCCR wished to revise the standardized frame.

Discussions with city representatives were resumed in the 2010s, at a time when many concession contracts signed 20 to 30 years earlier were expiring. Metropolitan elected officials were in somewhat more of a position of power than they had been at the beginning of the 1990s. The expertise of large cities had increased significantly with regard to energy issues. The jurisdictions of metropolises had grown, around the energy and climate plans and then the management of distribution networks (AODE status). Yet despite these advantages, city representatives experienced difficulties in obtaining additional progress on concession contracts. The directors of France urbaine, an association of elected officials which had become a rival of the FNCCR, hesitated to step into a new phase by requesting the dismantling of the centralized 
model: the end of the single rate (TURPE), the differentiation of concession contracts based on territories, and the placement of EDF-ENEDIS in a situation of competition. As many of them belonged to the Socialist Party, in reality they were very attached to the maintenance of the public monopoly, along with the majority of their voters. Moreover, they were on the same political side as the governments in power (under the presidency of François Hollande), which did not want to address a controversial issue at a time when they were experiencing significant difficulties. For this reason, France urbaine decided to nurture its relations with the FNCCR and its network of energy syndicates. EDF-ENEDIS changed little in its position. It became aware of the necessity of renewing political alliances by giving more weight to metropolises as emerging partners in the energy transition, but did not dare confront the FNCCR in the domain of differentiation, fearing that it would break the alliance established several years earlier.

In this context, in June 2016, France urbaine and EDF-ENEDIS signed an agreement protocol on new concession contracts ${ }^{18}$. In it, the association noted its commitment to equality in the treatment of territories and the maintenance of a single transportation rate. In return, EDF-ENEDIS made multiple commitments with regard to finance (greater transparency on the assets of concessions, an increase in royalties), investments (participation in the creation of metropolitan master plans), and environmental and societal actions (the fight against energy poverty, support promoting electro-mobility, experiments on smart networks, etc.). These provisions pushed the limits of a centralized system to the hilt. However, by no means did they undermine the principles of the organization and regulation of the electricity sector, thereby once again showing the capacity for resistance of the rural lobby. 


\section{Conclusion}

Because they are underpinned by a differentiation logic (between users, between operators, between spaces), in a context of decentralization, neoliberal reforms give rise to territorial conflicts in the regulation of the energy sector. Many rivalries have thus emerged within cities (Blanchet, 2015; Späth, Rohracher, 2015; Becker et al., 2017), between cities and states (Monstadt, 2007; Poupeau, 2014; Hannon, Bolton, 2015; Monstadt, Wolff, 2015; Rocholl, Bolton, 2016), and between cities and the rural territories surrounding them. This article has illustrated this by showing how, over the span of two decades, the control of these public electricity distribution networks in France has become a subject of major conflict between metropolitan and rural elected officials, due to the place occupied by infrastructure in the energy transition process. In fact, important issues come into play for local public authorities, with regard both to financing (capturing a portion of the profits generated by utilities) and to public policy (defending certain types of consumers, preserving the appeal of territories threatened by economic changes). These rivalries have led to strategies developed by both rural and metropolitan areas' representatives to control these infrastructures, by mobilizing many resources: institutional, political and legal (cf. Table $n^{\circ} 1$ ). As a result, a kind of "partition" of the French territory or, to put it another way, a new geopolitical order around the management of energy infrastructures, is emerging between, on the one hand, large syndicates representing rural areas, and, on the other, metropolises as they become more autonomous yet remain unable to contest the national frame and the main solidarity mechanisms.

These rivalries do not mean that urban and rural territories are necessarily opposed to one another in all respects. Forms of cooperation do also exist, for example with regard to the development of renewable energy sources (Géocarrefour, 2015). Yet at times they exist alongside more conflictual situations. It is therefore necessary to consider the urban-rural relationship in detail and in context, in relation to issues under scrutiny. To this end, the "local geopolitics" approach appears to be heuristically useful, precisely because it requires specific knowledge of the stakes (which are at times hidden) of territorial recompositions, as well as the set of political, economic, and legal resources that are mobilized by actors. While such an examination may seem very technical and dry for a non-specialist reader poorly 
informed of certain "technical" subtleties (legal rules, the analysis of the economic value chain, etc.), we nonetheless believe it to be essential, for otherwise we could fall into the trap of certain research on local governance which fails to carry out a detailed analysis of the fields of public action that it studies (territorialized political economy of the sector, analysis of the interplay of actors from a multi-level perspective, etc.).

Table $\mathbf{n}^{\circ} \mathbf{1}$. Resources used by rural and metropolitan areas' representatives to design a new geopolitics of distribution networks management in electricity

\begin{tabular}{|c|c|c|}
\hline Kind of resources & Rural areas' representatives & $\begin{array}{c}\text { Metropolitan areas' } \\
\text { representatives }\end{array}$ \\
\hline Intergovernmental networks & FNCCR & France Urbaine \\
\hline Institutional allies & $\begin{array}{c}\text { EDF (and ENEDIS) } \\
\text { Sinistry of Interior } \\
\text { Senate }\end{array}$ & $\begin{array}{c}\text { Actors calling for large-scale } \\
\text { decentralization (in State } \\
\text { administrations, associations } \\
\text { of local authorities, new } \\
\text { operators, NGOs, etc.) }\end{array}$ \\
\hline Political arguments & $\begin{array}{c}\text { National solidarity } \\
\text { Protection of the national } \\
\text { champion (EDF) against } \\
\text { liberalization }\end{array}$ & $\begin{array}{c}\text { Globalization (through strong } \\
\text { metropolises) } \\
\text { Energy transition (urban } \\
\text { areas as key territories) }\end{array}$ \\
\hline Legal aspects & $\begin{array}{c}\text { Concession contracts with EDF } \\
\text { (incentives) } \\
\text { Laws of 2006 and 2010 } \\
\text { (promotion of large syndicates } \\
\text { in energy) }\end{array}$ & $\begin{array}{c}\text { Laws of 2014 (creation of } \\
\text { metropolises) and 2015 } \\
\text { (energy transition) }\end{array}$ \\
\hline
\end{tabular}

EDF: électricité de France; FNCCR: Fédération nationale des collectivités concédantes et régies; NGO: Non-governmental organization.

Beyond energy, one of the major findings of this article is to show that metropolization processes must not be analysed solely through the lens of the rescaling strategies carried out by states over the past twenty years or more (Brenner, 2004; Jonas, Ward, 2007; Kübler, Lefèvre, 2018) or the ability of metropolises to establish themselves as collective actors (Le Galès, 2002; Heinelt, Kübler, 2005; Kantor et al., 2012; Evers, de Vries, 2013; Keil et al., 2016). The 
policies followed by states are certainly central for explaining and understanding these phenomena, in view of the major role that they play in territorial recompositions. Moreover, metropolises' assertion of their role depends on the ability of their political and administrative elite to rally and federate the actors in their territory around a common political project. These two classic explanatory factors could however be improved by an analysis of the power relations that link metropolises to other local political institutions (regions, provinces, counties, rural communes, etc.). The example of energy illustrates this well. The obstacles that metropolises encounter in their quest for leadership in energy do not stem solely from the attitude of the state, which in France is more reluctant to liberalize the sector than in other countries, in order to preserve its "national champion" (EDF) and its social model, which is highly redistributive. They also stem from the existence of powerful rural institutions in this sector at both local (departmental energy syndicates) and national (the FNCCR) levels. In favour of maintaining a form of centralization, today, these institutions play an important counter-power role in the metropolization process by opposing differentiation strategies. To do so, they mobilize numerous resources, as noted above. It is by also looking at this type of actor, midway between the national (state) and local (metropolises) levels, that we can better understand the metropolization process.

\section{Notes}

1. FNCCR, "Quel mode de gestion pour les services publics locaux de l'électricité ?", 2011, pp. 14-15 (the statistics are those of INSEE, 2007).

2. This publication draws on research on the French energy sector over the past twenty years, which has resulted in multiple publications in French. For more information, see the methodological annex. We thank Daniel Florentin, Olivier Labussière and Jonathan Rutherford for their opinions and advice.

3. Created under the French Revolution, communes (or municipalities) constitute the smallest politico-administrative division in the country. They are headed by a mayor elected through indirect universal suffrage. The population of the 35,000 French communes ranges from a few inhabitants to several million (Paris, Lyon, Marseille, etc.). 
4. Poupeau, 2017. It amounted to 400 million in 2017 (source: Sénat).

5. With around 170 local distribution companies that service $5 \%$ of the French territory. On these actors, cf. Gabillet, 2015.

6. CRE.

7. CRE.

8. Cour des comptes, Rapport public annuel 2013, p. 133.

9. CRE, 2017.

10. A report from the Cour des comptes (doc. cit., pp. 140-141) mentions the fact that EDF-ENEDIS serves as a veritable "cash cow" for its shareholder EDF (financing of its international investment policy) and indirectly for the French state (reduction of public deficits). Between 2008 and 2011, ENEDIS often paid at least $75 \%$ of its net profit to its parent company.

11. In 2017, France had 101 départements. As their size is between that of communes and that of regions, départements are political and administrative areas which allow for solidarity between rural and urban areas. Attaining this size is therefore an essential goal for syndicates.

12. SEA Conseil en stratégie, Altime Charles Riley, "La distribution d'électricité en France. Quelles évolutions ? Organisation territoriale de l'énergie et évolution des métiers", Janvier 2011). The data that follow are drawn from this study (sample: $\mathrm{n}=57)$.

13. SEA Conseil en stratégie, Altime Charles Riley (doc. cit., p. 11). Translated from French by the author.

14. The Association des maires des grandes villes de France (the association of mayors of large cities in France) was created in 1974.

15. Loi de programmation fixant les orientations de la politique énergétique (the framework legislation establishing the orientations of the energy policy).

16. The MAPTAM Law (Modernisation de l'action publique territoriale et d'affirmation des métropoles, Modernization of public territorial action and affirmation of metropolises) of January 27, 2014 and the NOTRe law (on the New territorial organization of the Republic, Nouvelle organisation territoriale de la République) of August 17, 2015.

17. With the exception of the Metropolis of Greater Paris, which did not obtain this jurisdiction.

18. From the France urbaine website. 


\section{Bibliography}

Becker S, Naumann M and Moss T. (2017) Between coproduction and commons: understanding initiatives to reclaim urban energy provision in Berlin and Hamburg. Urban Research \& Practice 10(1), 63-85.

Bellanger E and Poupeau FM (2013) Lumières sur la banlieue. Histoire du syndicat intercommunal de la périphérie de Paris pour l'électricité et les réseaux de communication (SIPPEREC). Paris: Les Éditions de l'Atelier.

Birchfield VL and Duffield JS (eds) (2011) Towards a Common European Union Energy Policy: Problems, Progress, and Prospects. London: Palgrave.

Blanchet T (2015) Struggle Over Energy Transition in Berlin: How Do Grassroots Initiatives Affect Local Energy Policy-Making? Energy Policy 78, 246-254.

Boyer M (2019), Les syndicats d'énergie : bras armés des collectivités territoriales dans la transition énergétique? Working Paper of LATTS 19-17 (https://halenpc.archives-ouvertes.fr/hal-02166300).

Brenner N (2004) New States Spaces. Urban Governance and the Rescaling of Statehood. Oxford: Oxford University Press.

Bulkeley H (2013) Cities and Climate Change. London: Routledge.

Chick M (2007) Electricity and Energy Policy in Britain, France and the United States since 1945. Cheltenham, Northampton: Edward Elgar.

Cohen S (2015) Geopolitics. The Geography of International Relations. London: Rowman \& Littlefield.

Considine JI and Paik KW (eds) (2018) Handbook of energy politics, Cheltenham (UK), Northampton (Mass.): Edward Elgar.

Coutard $O$ and Rutherford J (2011) The rise of post-networked cities in Europe? Recombining infrastructural, ecological and urban transformations in low carbon transitions. In: Bulkeley H, Castan Broto V, Hodson M and Marvin S (eds) Cities and Low Carbon Transitions. London: Routledge, pp. 107-125.

Davidson DJ and Gross M (eds) (2018) The Oxford Handbook of Energy and Society, Oxford University Press. 
Energy Policy (2015) Urban energy governance: local actions, capacities and politics. Special issue 78.

Evers D and de Vries J (2013) Explaining Governance in Five Mega-City Regions:

Rethinking the Role of Hierarchy and Government. European Planning Studies, 21(4), 536-555.

Frost RL (1991) Alternating currents. Nationalized Power in France, 1946-1970.

Ithaca and London: Cornell University Press.

Gabillet $\mathrm{P}$ (2015) Les entreprises locales de distribution à Grenoble et Metz : Des outils de gouvernement énergétique urbain partiellement appropriés, $\mathrm{PhD}$ Thesis, University of Paris-Est.

Géocarrefour (2015) Les campagnes dans la transition énergétique. Special issue 90(4).

Glachant JM and Finon D (2003) Competition in European Electricity Markets. A Cross-country Comparison, Cheltenham (UK), Northampton (USA): Edward Elgar.

Goldthau A (ed.) (2013) Handbook of Global Energy Policy, John Wiley \& Sons.

Goldthau A, Keating F and Kuzemko C (eds) (2018) Handbook of the international political economy of energy and natural resources, Northampton (USA): Edward Elgar.

Graham S and Marvin S (2001) Splintering Urbanism. Networked Infrastructures, Technological Mobilities and the Urban condition. Routledge, London.

Hannah L (1979) Electricity before Nationalization A Study of the Development of The Electricity Supply Industry in Britain to 1948. London, Basingstoke: Macmillan Press.

Hannon MJ and Bolton R (2015) UK Local Authority engagement with the Energy Service Company (ESCo) model: Key characteristics, benefits, limitations and considerations. Energy Policy 78, 198-212.

Heinelt H and Kübler D (eds) (2005). Metropolitan Governance: Capacity, Democracy and the Dynamics of Place. ECPR Series in European Political Science. London: Routledge. 
Jonas AEG and Ward K (2007) Introduction to a debate on city-regions: New geographies of governance, democracy and social reproduction. International Journal of Urban and Regional Research 31(1), 169-178.

Kantor P, Lefèvre C, Saito A, Savitch HV and Thornley A (2012) Struggling Giants. City-Region Governance in London, New York, Paris and Tokyo. Minneapolis: University of Minnesota Press.

Keil R, Hamel P, Boudreau JA and Kipfer S (2016) Governing Cities Through Regions. Canadian and European Perspectives. Wilfried Laurier University Press.

Kübler D and Lefèvre C (2018) Megacity governance and the state. Urban Research \& Practice, 11 (4): 378-395.

Kuisel RF (1984) Le capitalisme et l'État en France. Modernisation et dirigisme au $X X^{\circ}$ siècle. Paris: Gallimard.

Le Galès P (2002) European Cities. Social Conflicts and Governance. New York: Oxford University Press.

Lévy-Leboyer M and Morsel H (eds) (1994) Histoire de l'électricité en France. Tome deuxième : 1919-1946. Paris: Fayard.

Lorrain D (1992) The French Model of Urban Services. West European Politics 15(2), 77-92.

Mahoney $\mathrm{J}$ and Thelen K (2010) A Gradual Theory of Institutional Change. In: Mahoney, J., Thelen, K. (eds) Explaining Institutional Change: Ambiguity, Agency, and Power. Cambridge: Cambridge University Press, pp. 1-37.

Marcou G, Eiller AC, Poupeau FM and Staropoli C (eds) (2015) Gouvernance et innovations dans le système énergétique. De nouveaux défis pour les collectivités territoriales ? Paris: L'Harmattan.

Matlary JH (1997) Energy Policy in the European Union, New York: St Martin's Press.

Mc Gowan F (ed.) (1996) European Energy Policies in a Changing Environment. Heidelberg: Physica-Verlag. 
Monstadt J (2007) Urban Governance and the Transition of Energy Systems: Institutional Change and Shifting Energy and Climate Policies in Berlin. International Journal of Urban and Regional Research 31(2), 326-343.

Monstadt $J$ and Wolff A (2015) Energy transition or incremental change? Greenpolicy agendas and the adaptability of the urban energy regime in Los Angeles. Energy Policy 78, 213-224.

Poupeau FM (1999) EDF ou la permanence d'un " compromis républicain ». Le système de distribution électrique français entre État et collectivités locales, de la nationalisation à la mondialisation, PHD Thesis, Institut d'Études Politiques de Paris.

Poupeau FM (2004) Le service public à la française face aux pouvoirs locaux. Les métamorphoses de l'État jacobin. Paris: CNRS Éditions.

Poupeau FM (2007) La fabrique d'une solidarité territoriale. État et élus ruraux dans l'adoption d'une péréquation des tarifs de l'électricité en France. Revue française de science politique 57(5): 599-628.

Poupeau FM (2014) "Central-Local Relations in French Energy Policy-Making: Towards a New Pattern of Territorial Governance". Environmental Policy and Governance 24(3): 155-168.

Poupeau FM (2015) Ce que le contrat fait à la gouvernance territoriale. La transformation du paysage institutionnel de la distribution publique de l'électricité en France depuis les années 1990. Politiques et management public 32(3): 211-240.

Poupeau FM (2017) L'électricité et les pouvoirs locaux en France (1880-1980). Une autre histoire du service public. Bruxelles: Éditions Peter Lang (collection « Histoire de l'énergie »).

Rhodes RAW and Marsh D (1992) Policy Networks in British Government. Oxford: Oxford University Press.

Rocholl N and Bolton R (2016) Berlin's electricity distribution grid: an urban energy transition in a national regulatory context, Technology Analysis \& Strategic Management 28(10), 1182-1194.

Sack RD (1986) Human Territoriality. Its Theory and History. Cambridge: Cambridge University Press. 
Scott AJ (ed.) (2001) Global city-regions: trends, theory, policy. Oxford: Oxford University Press.

Späth P and Rohracher H (2015) Conflicting strategies towards sustainable heating at an urban junction of heat infrastructure and building standards. Energy Policy 78, 273-280.

Urban Studies (2014) Urban energy transitions: Places, processes and politics of socio-technical change. Special issue 51(7).

Wollmann H and Marcou G (2010) The Provision of Public Services in Europe. Between State, Local Government and Market. Cheltenham: Edward Elgar. 


\section{Methodological annex}

This article is based on a longitudinal analysis of the transformations that have affected the public electricity distribution sector in France from the 1990s to the 2010s. It draws on several successive surveys, archives, interviews (200 for the whole period) and participation in formal and informal meetings.

The historical aspects (up to the 1990s) are based on two main works.

Research study 1. This historical analysis (before liberalization) is based on the consultation of archives provided by the state, EDF and the FNCCR. This work was published in a book (Poupeau, 2017).

Research study 2. The recomposition of the 1990s was analysed in a PhD thesis defended in 1999 at Sciences Po Paris (former Institut d'études politiques de Paris) on the strategy of contracting between EDF and local authorities (Poupeau, 1999). 100 semi-structured interviews were conducted with actors at national (definition of contract clauses) and local levels (implementation of contractualization and resistance phenomena).

Changes during the years 2000 have been analyzed through nine research studies.

Research study 3. A seminar on the role of local authorities in the energy transition process, bringing together academics and professionals (representatives of local authorities, state administrations, operators, NGOs, etc.). It was co-organized with the French Ministry of Ecology in 2008-2009 (10 workshops). Files are available at the website http://www.urbanisme-puca.gouv.fr/politiques-energetiques-locales-20082009-a378.html

Research study 4. A case study about the history of the Sipperec (1924-2013), which is the largest energy syndicate in France (archives, interviews). This monograph was published in 2013 (Bellanger and Poupeau, 2013). 
Research study 5. Participation, as an academic expert, in the national debate organized by the French Ministry of Ecology to prepare the vote on the law of 2015 on energy transition (participation in the group working on the issues of governance) (no publication).

Research study 6. Survey on the strategy of ENEDIS (EDF) to negotiate new concession contracts with local authorities (2013-2014): interviews with ENEDIS executives and representatives of the FNCCR and France Urbaine (no publication for the moment, elements in Bellanger and Poupeau, 2013).

Research study 7. Co-organization of an academic seminar about territorial innovation in the field of energy (Marcou et al., 2015).

Research study 8. Coordination (with Carine Staropoli, Paris School of Economics) of a survey "New contractual practices in the distribution of energy in France and Europe" (2016, in partnership with the French energy council).

Research study 9. Supervision of a Master's thesis "Analyse des contrats de concession de distribution publique de gaz et d'électricité. Vers une recomposition de la politique publique locale de l'énergie ? " (Corinne Belvèze, with the City of Paris).

Research study 10. Supervision of a PHD thesis 'Les stratégies de transition énergétique des métropoles françaises' (Mathilde Marchand, started in 2017).

Research study 11. Supervision of a survey on the energy syndicates in France, with a quantitative (status, organizations, budgets, fields of intervention) and qualitative methodology (two case studies on the cooperation between syndicates, regions and metropolises) (Boyer, 2019). 